\title{
A PPP mint gyűjtőfogalom
}

\author{
közszektor és magánszektor - együttmüködés - PPP típusok - \\ közfeladat-ellátási alternatíva
}

A PPP - Public-Private Partnership - napjainkra elterjedt, közismert fogalommá vált, mely legtöbbször a különböző infrastrukturális beruházásokkal összefüggésben hangzik el. Megkockáztatom, az is közismert tény, hogy e jogintézménynek számtalan típusa, alfaja létezik. Az 1970-es évek végén, 1980-as évek elején indult hódító útjára a nyugati angolszász államokból, majd terjedt tovább a nyugat-európai kontinentális államokba, mely folyamatra az Európai Unió katalizátorhatást gyakorolt. A PPP a kelet-közép-európai államokba a 21. század elejére jutott el, amiben ezen államoknak az Unióhoz való csatlakozása meghatározó szerepet játszott. A keletközép-európai államokon kívül e jogi konstrukciót a 21. századra elsősorban a különböző nemzetközi szervezetek közvetítő tevékenysége okán kezdték alkalmazni a kevésbé fejlett afrikai és ázsiai államok alapvető infrastrukturális létesítményeinek kiépítésére, illetve fejlesztésére.

A kezdetek kezdetén indult PPP-projektek tapasztalatait a szakirodalom az 1990-es évek végére, 2000-es évek elejére dolgozta fel. Az elmúlt több mint harminc évben természetesen számos alakváltozata alakult ki a PPP-nek, melyek akár országcsoportonként is vizsgálhatók volnának (például kontinentális nyugat-európai államok, rendszerváltó államok), ahogyan a vele kapcsolatban megfogalmazott kritikai észrevételek, s azokra reakcióként megjelent Public-Public Partnership (PuP) ügyletek is, melyek igen különleges újraértelmezései az eredeti PPP-konstrukciónak, külön vizsgálat tárgyát képezhetnék. Ám mielött még a jogintézmény sajátos formációit, alakváltozatait vagy vele kapcsolatban a napjainkban aktuális folyamatokat vizsgálnánk, érdemes tisztázni, hogy mit is értünk a PPP fogalma alatt, amiben úgy gondolom, leginkább az angolszász irodalom lehet segítségünkre. Jelen tanulmány a PPP eredeti definícióját s típusait igyekszik feltárni, melyek az elmúlt évtizedekben az őket életre hívó társadalmi, gazdasági és költségvetés-politikai igényekhez való alkalmazkodás során módosultak. Arra keresem a választ tehát, hogy mit takar pontosan eredetileg a PPP kifejezés, s annak milyen típusai léteznek. Hogyan ragadható meg a lényege? Mitől vált a jogintézmény világszerte elterjedtté?

Érdemes megjegyezni, hogy a PPP szerződéseknek több konkuráló jelölése is ismert a nemzetközi szakirodalomban. Ilyen a Világbank által használt PPI, mely a Private Participation in Infrastructure kifejezést takarja, amely egyértelmüen utal

* Dr. Varga Judit egyetemi tanársegéd, Debreceni Egyetem Állam- és Jogtudományi Kar Pénzügyi Jog és Közmenedzsment Tanszék, varga.judit@law.unideb.hu. 
rá, hogy e megállapodások elsősorban a magánszektor közösségi igénnyel létrejövő infrastrukturális beruházásokba vonását célozza. Ehhez nagyon hasonló a fejlesztési bankok által alkalmazott PSP kifejezés, vagyis Private-Sector Participation. Észak-Amerikában a P3, míg Ausztráliában a PFP (Privatly-Financed Projects - magánfinanszírozású projektek) rövidítés alkalmazott. Ismert még a $P$-P Partnership jelölés is, mely azt a célt szolgálja, hogy e szerződések rövidítése ne legyen öszszetéveszthető a vásárlóerő-paritás purchasing power parity rövidítésével (ppp). Az Egyesült Királyságban és annak hatása miatt Japánban és Malajziában használatos a PFI (Private Finance Initiative) kifejezés, mely nyersfordításban magánfinanszírozású kezdeményezésként értelmezhető. ${ }^{1}$ A továbbiakban e szerződések jelölésére a PPP rövidítését fogom használni.

\section{A PPP megjelenésének okai}

A PPP-szerződések megjelenésére és későbbi népszerüségére három körülmény szolgált indokul. ${ }^{2}$ Egyrészt a nyugati szociáldemokrata kormányzatokat az 1979-es olajválság idején sújtó fiskális kihívások. Ezek testet öltöttek a közösségi szükségletek növekedésében, ami gyorsabb ütemü volt, mint az egyes államok gazdasági növekedésének mértéke. Az újonnan megjelenő igények kielégítése és természetesen a már az állam által felvállalt közfeladatok ellátása igen erős nyomás alá helyezte az épp hatalmon lévő kormányzatokat. Másrészt a polgárok nemcsak jobb minőségű és több típusú közszolgáltatást vártak el az állam irányítóitól, hanem a közterhek csökkentését is, ${ }^{3}$ aminek a megvalósításakor a kormányzatok az első elvárásnak - vagyis a több és magasabb színvonalú közszolgáltatás-nyújtás igényének - még kisebb valószínüséggel lennének képesek megfelelni. Azonban azáltal, hogy a PPP-megállapodásokból fakadó költségek nagy részét lehetőség nyílt költségvetésen „kívül tartani” (off-balance-sheet financing), ${ }^{4}$ fokozódott e megoldások iránt a kormányzati érdeklődés.

A fiskális kihívásokon túl említhetjük még az államok saját szerepfelfogásukról vallott képének időközbeni megváltozását is. A második világháború után kialakult aktivista kormányzati felfogást az 1970-es évek végétől, 1980-as évek elejétöl felváltották a liberális nézetek, vagyis azok az elgondolások, ${ }^{5}$ melyek az állam gazdasági és társadalmi szerepvállalásának redukálása mellett foglaltak állást. A PPP-szerződések során megvalósult létesítmények kivitelezése, müködtetése illeszkedett a liberális nézetrendszerbe, hisz lehetővé tette, hogy az állam a közösségi igények ki-

1 Yescombe, E. R.: Public-Private Partnerships - Principles of Policy and Finance. Elsevier, London, $2007,4$.

2 LoxLey, John-LoxLey, Salim: Public Service Private Profits. The Political Economy of Public-Private Partnerships in Canada. Fernwood Publishing, Halifax-Winnipeg, 2010, 5-8.

3 Összefüggésben a politikai váltógazdaságból fakadó kormányzati kudarcokkal. Lásd NEMEC, Juraj: Kormányzati szerepvállalás közgazdasági és társadalmi alapjai. In: Nemec, Juraj-Wright, Glen (szerk.): Közösségi pénzügyek. Elmélet és gyakorlat a közép-európai átmenetben. Aula Kiadó, Budapest, 2000, 63-101.

4 Eurostat (2004): New decision of Eurostat on deficit and debt. Treatment of public-private partnerships. STAT/04/18. Forrás: http://europa.eu/rapid/press-release_STAT-04-18_en.htm (2015. 05. 22.).

5 WRIGHT, Glen: A kormányzat szerepe. In: Nemec-Wright: i. m., 18-56. 
elégítésébe bevonja más szektorbeli szereplők - elsősorban a magánszektor - forrásait, szaktudását, s velük együtt a piaci törvényszerüségeket, és ezzel, amennyire csak lehet, kivonuljon az egyes szolgáltatások nyújtásából.

A harmadik indok, ami hozzájárult a tárgyalt jogintézmény népszerüségéhez, hogy a magánszektor alanyai lehetőséget láttak e konstrukciók keretében a profitszerzésre. Mondhatni, a piaci lehetőségek tágítását is jelentették a fenti szerződések, tekintve, hogy megnyitották az eredetileg kizárólag az állami - vagyis a közszektorbeli - szereplők által ellátott szolgáltatások piacát más közfeladat-ellátási szektorból érkező alanyok előtt is.

\section{A PPP fogalma}

A hazai jogirodalom viszonylag kevés monografikus forrással segíti a PPP fogalmának értelmezését. A témával először bővebben egy Leiner szerkesztette minisztériumi kiadvány foglalkozott 2004-ben, mely szerint „... a Public Private Partnership, [...] az állam és a magánszféra olyan együttmüködési formáját jelenti, amelyben a felek a közszolgáltatás-nyújtásnak felelősségét és kockázatát közösen viselik". E fogalom általában a közszolgáltatás-nyújtást jelöli meg eme ügyletek tárgyaként, s nem választja külön e szolgáltatások biztosításához szükséges infrastrukturális háttér megteremtését, illetve az - esetlegesen az előbbihez kapcsolódó - szolgáltatás biztosítását, ezzel tágan határozza meg a PPP-szerződések tárgyát. Az Állami Számvevőszék e témában készített 2007-es jelentése már egy szükebb PPP-definícióval operál, mely szerint a PPP „...a köz- és magánszféra olyan - többnyire fejlesztési - együttmüködését jelenti, amelyben a közfeladathoz kötődő tervezési, építési, müködtetési és finanszírozási feladatokat az állam a megszokottnál nagyobb vagy teljes mértékben, jellemzően komplexebb módon bízza a magánszektorra".7 Az ÁSZ már elsősorban a közfeladathoz kapcsolódó fejlesztési, azon belül is inkább az építési beruházásokra fókuszálva határozza meg a PPP-ügyletek tárgyát. Müködtetési feladatokat is említ, a létrehozott infrastruktúra üzemeltetésével összefüggésben. A közpénzügyek nagy kézikönyve című kötetben (2009) ${ }^{8}$ a PPP-t mint közfeladat-ellátási konstrukciót Hamza Lászlóné tárgyalja, aki teljes mértékben az előbb bemutatott ÁSZ-jelentés által használt fogalmi meghatározást veszi át. Nyikos Györgyi monográfiája (2010) a tárgyalt jogintézménynek az Európai Unió fejlesztési és támogatási rendszerébe ágyazhatóságát vizsgálta, s a magyar jogirodalomból a 2004-es, Leiner által szerkesztett kiadvány tágabb fogalmához nyúlik vissza, melynek kapcsán kiemeli, hogy „közcélú beruházások megvalósításáról, illetve közszol-

6 Leiner Vera (szerk.): PPP-kézikönyv: a köz- és magánszektor sikeres együttmüködése. GKM Protokoll és Sajtófőosztály, Budapest, 2004, 9.

7 ÁSZ: A köz- és magánszféra együttmüködésével kapcsolatos nemzetközi és hazai tapasztalatok. 2007, 74. Forrás: http://www.asz.hu/tanulmanyok/2007/a-koz-es-maganszfera-egyuttmukodesevel-kapcsolatosnemzetkozi-es-hazai-tapasztalatok/t134.pdf (2015. 09. 07.).

8 Zsugyel János-ARADI Zsolt-BATHó Ferenc et al.: A közpénzügyek nagy kézikönyve. CompLex, Budapest, 2009, 207-234. 
gáltatások nyújtásáról van szó" a PPP-konstrukciók esetén. ${ }^{9}$ Nagyon érdekes, hogy bár a fentiek közül két munka is tágan határozza meg a PPP tárgyát, azonban a hazai gyakorlat, és sok esetben a jogirodalom is elsősorban az épitési beruházásokkal összefüggő projektre asszociál a PPP kapcsán, holott nemcsak infrastrukturális beruházásokkal összefüggésben, hanem ehhez képest jóval tágabb körben képzelhető el a köz- és magánszektor közötti szerződéses együttmüködés. Egyrészt eme előbbi jelenség, vagyis a PPP fogalmának szűkebb gyakorlati értelmezése, másrészt a hazai szakirodalomban megfigyelhető egymásra hivatkozás, és a külföldi források korlátozott vizsgálata indított arra, hogy a PPP eredetileg kialakult fogalmának értelmezése $s$ csoportosítási lehetőségeinek feltárása érdekében a vizsgált irodalmak körét kiterjesszem.

A PPP fogalmának meghatározása nehézségekbe ütközik, hisz maga a kifejezés más-más jelentéstartalommal bír az egyes országokban, sőt akár egy országon belül is, ha különböző közfeladat-ellátási szektorokat vizsgálunk. Sőt a PPP-szerzödések közé sorolandó megállapodások tartalmát és lényegét is eltérően határozzák meg az államok. ${ }^{10}$

A köz- és magánszektor közötti partnerség kanadai tanácsa (Canadian Council for Public-Private Partnerships) szerződéses együttmüködésen alapuló üzleti vállalkozásként definiálta a PPP-t, mely a köz- és a magánszektor alanyai között jön létre, és épít valamennyi fél szaktudására. A szektorok közötti együttmüködés célja infrastrukturális létesítmények javítása, fejlesztése, illetve szolgáltatások nyújtása a közszektor nevében, melynek során megvalósul az erőforrások, a kockázatok és a felelösség megfelelő és fair elosztása a partnerek között. ${ }^{11}$

Weber és Alfen a PPP-szerződések definícióját e megállapodások fő jegyeinek, közös sajátosságainak felsorolása révén látják korrekten megadhatónak, tekintettel az egyes államok közötti különbségekre, illetve e kontraktusok számos altípusára. ${ }^{12}$ A szerzőpáros a PPP-megállapodások közös jegyeinek tekinti az életciklus-szemléletet, amit a szerzőpáros bővebben nem fejt ki, ám megítélésem szerint kettős jelentéstartalmat hordoz. Kifejezi az egyes beruházások életciklusainak elkülönítését, és az egyes ciklusokban a szerződésben részes felek feladatainak, felelősségének a megosztását. De jelenti e hosszú távra szóló megállapodásoknak az előkészítéstől a szerződéses idő végéig tartó figyelemmel kísérését is, $s$ e folyamat egységes rendszerben való kezelését. További közös vonás a közfeladat-ellátási hatékonyság növelésének célja, a felek közti feladatok megfelelő elosztása útján. Lényeges sajátossága e kontraktusoknak a szerződéses partnerek közötti kiegyensúlyozott kockázatmegosztás, melynek során a magánszektorbeli alanyra történő valós, tényleges kockázatátruházásra kell törekedni. Elöbbieken túl a magánszektor

9 NYıкos Györgyi: A PPP finanszírozási technika és az EU fejlesztési támogatásai a közcélú beruházások megvalósításában. ELTE Eötvös Kiadó, Budapest, 2010, 17-18.

10 DeLmon, Jeffrey: Understanding Options for Public-Private Partnerships in Infrastructure - Sorting out the forest from the trees: BOT, DBFO, DCMF, concession, lease... The World Bank, 2010, https://openknowledge. worldbank.org/bitstream/handle/10986/19947/WPS5173.pdf?sequence=1 (2015. 05. 12.) 5.

11 http://www.pppcouncil.ca/resources/about-ppp/definitions.html (2015. 02. 27.).

12 Alfen, Hans Wilhelm-Weber, Barbara: Infrastructure as an Asset Class. Investment Strategies, Project Finance and PPP. UK, Wiley Publication, 2010, 65. 
innovációs potenciáljának ösztönzése végett eredményorientált teljesítményleírás és ellentételezés alkalmazása, valamint a magánszektor szakértelmének és tőkéjének használata is közös vonása az egyes PPP-szerződéseknek. Valamennyi, a szektorok közötti partnerségi együttmüködés tartalma hosszú távra szóló megállapodásban szabályozott, míg a szerződésben nem rendezett kérdésekre vonatkozó szabályanyag megalkotásának joga és a megállapodások teljesítésével összefüggő ellenőrzés a közszektorbeli alanyt illeti meg.

Duffield megítélése szerint a PPP-k hosszú távra, tipikusan 25 évre születő szerződéses megállapodások, melyeket a kormányzat ${ }^{13}$ köt másik féllel, aki legtöbbször speciális rendeltetésű társaságként (Special Purpose Vehicle - SPV) - hazánkban projekttársaságként - tűnik fel. A szerződés célja egy meghatározott szolgáltatás nyújtása a szerződésben meghatározott időintervallumon keresztül vagy időpontig, ami több egy vagyonelemnek a közszektorbeli szereplő rendelkezésére bocsátásánál. A szerződésben vállalt kötelezettségekért cserébe az ellentételezés alapulhat direkt módon a fogyasztó által a szolgáltatásért fizetett díjakon, vagy a kormányzat által, teljesítményalapon megállapított kifizetéseken. Duffield jelzi, hogy fogalomalkotása hozzávetőleges, elsősorban a PPP-megállapodások rendszertani elhelyezését szolgálja, semmint annak egzakt definiálását, tekintettel arra, hogy a különböző nemzetközi szervezetek, illetve államok között sincs teljes összhang a tekintetben, hogy mit is takar a kifejezés, és pontosan milyen szerződéstípusok értendők alatta. ${ }^{14}$

Yescombe Weberhez és Alfenhez hasonlóan közelíti meg a PPP fogalmát. Azt mondja, hogy PPP-nek minősülnek mindazok a szerződéses megállapodások a köz- és magánszektorbeli alanyok között, melyek a következő tulajdonságokkal bírnak. Ilyen, hogy a kontraktusok hosszú távra jönnek létre a felek között. A szerződés tárgya, hogy a magánszektorbeli alany végezze el valamely közösségi infrastruktúra tervezését, létesítését, finanszírozását és/vagy működtetését. A magánpartner számára az infrastruktúra használatáért való ellentételezést vagy a közszektorbeli alany fizeti meg a szerződési határidő alatt, vagy közvetlenül a szolgáltatás igénybe vevői, fogyasztói. A létesítmény tulajdonjoga vagy a közszektorbeli alanynál marad, vagy csak a szerződési határidő letelte után kerül hozzá. Vagyis Yescombe is e szerződések fő jegyeinek meghatározásában látja a PPP-jogintézmény definiálásának lehetőségét. ${ }^{15}$

Delmon tágan értelmezi a PPP fogalmát, mikor azt mondja, hogy PPP-nek tekinthető minden szerződéses és más típusú jogi kapcsolat a köz- és a magánszektorbeli alanyok között, melynek célja az infrastrukturális szolgáltatások fejlesztése és/vagy kiterjesztése. ${ }^{16} \mathrm{Ez}$ a definíció valóban kiterjeszti a tárgyalt jogintézményt, ráadásul, ha szerződésen kívüli más jogi reláció is létrehozhat ilyen kapcsolatot a köz- és a magánszektor alanyai között, akkor megítélésem szerint a PPP-ügyletek lényeges eleme veszne el: a partnerség, a felek közti akarategyezőség. Egy másik

13 Értve itt a központi és az alatt elhelyezkedő kormányzatokat.

14 Duffield, Colin F.: Different Delivery models. In: Graeme A., Hodge-Carsen, Greve-Boardman, Anthony E. (eds.): International Handbook on Public-Private Partnerships. MPG Books Group, Cheltenham (UK), 2010, 187-193. 
Delmon által használt fogalom, melyet a Világbank is magáénak tud, úgy hangzik, hogy a PPP nem más, mint megállapodás a magánszektorral, hogy az biztosítson infrastrukturális szolgáltatásokat a köz javára, vagy segítse a közszektort, miközben infrastrukturális szolgáltatásokat nyújt a közösség javára. ${ }^{17}$

A PPP-re az Európai Unió által alkalmazott fogalmi meghatározást a Bizottság 2004-es Zöld könyvében találjuk. ${ }^{18}$ Lényeges, hogy uniós szinten a PPP fogalma nincs kötelező jogi aktusban tisztázva. A kifejezés olyan együttműködésre utal a közés a magánszektorból származó alanyok között, amelynek célja valamilyen infrastruktúra finanszírozása, létesítése, felújitása, karbantartása, vezetése vagy valamilyen szolgáltatás biztosítása. Más, korábban bemutatott szerzőkhöz hasonlóan, a Bizottság is felsorolja a tipikus karakterjegyeit eme szerződéses megállapodásoknak, mint azt, hogy hosszú távra születő ügyletekröl van szó, melyek magánszektorbeli és közszektorbeli alanyok közötti együttmüködést takarnak. A megvalósuló projektet részben a magánszektorból érkező fél, részben a közszektorbeli alany finanszírozza. A projekttel kapcsolatos kockázatok pedig megoszlanak a felek között.

Bár tökéletes összhang nincs a különböző meghatározások között, valamennyien megegyeznek abban, hogy a PPP a köz- és magánszektorbeli partnerek között, hosszabb távra (több évre), közfeladat-ellátási céllal létrejövő megállapodás. Véleményem szerint a PPP kifejezés gyüjtöfogalom, amely magába olvaszt valamennyi köz- és magánszektorbeli alany között közfeladat-ellátási céllal - legyen ez közösségi igényeket kielégítő infrastruktúrával összefüggő vagy attól független feladat több évre létrejövő szerződéses megállapodást. Az így kapott definíció igen tágan húzza meg e jogintézmény „határait”, s igen változatos együttmüködési formációknak enged teret. A továbbiakban azt nézem meg, hogy hogyan is tipizálhatók a PPP mint gyüjtőfogalom alá tartozó közfeladat-ellátási megoldások.

\section{A PPP-megállapodások fajtái}

A PPP-megállapodások több szempont szerint is csoportosíthatóak. Nézzük a legátfogóbb csoportosítási lehetőségeket.

\subsection{PPP-szerződések a magánszektorbeli alany közfeladat-ellátásba való bevonásának mértéke szerint}

A magánszektorbeli alany közfeladat-ellátásba való bevonásának mértéke szerint a különbségtétel alapja az egyes szerződések között az, hogy a kontraktus eredményeként milyen mértékben kerülnek bevonásra a magánszektorbeli alanyok a közfeladat-ellátásba. A két végletet ez esetben a tág értelemben vett privatizáció és a hagyományos közfeladat-ellátási megoldások képezik. Tágan értelmezett privatizá-

Delmon: i. m., 7.

18 Green Paper on Public-Private Partnerships and Community Law on Public Contracts and Concessions. COM(2004) 327 final. HL. 2004. 04. 30. 
ció ${ }^{19}$ esetén az állam teljes egészében kivonul a korábban közfeladatnak minősített teendő ellátásából, s azok biztosítását más közfeladat-ellátási szektorokra, fő szabály szerint a piaci szektorra bízza. A hagyományos értelemben vett közfeladat-ellátási megoldások esetén az állam gondoskodik a közösségi szükségleteket kielégítő szolgáltatások nyújtásáról, így ő biztosítja a szükséges pénzügyi fedezetet, vagyontárgyakat, személyzetet, melyek a feladatok ellátásához szükségesek. Az elöbbi két véglet között elhelyezkedő szerződéses megoldásokat - melyek közösségi igények kielégítését célozzák, $\mathrm{s}$ amelyekben mind a közszektor, mind a profitorientált magánszektor részt vesz - tekinti Loxley PPP-szerződéseknek. Megjegyzendő, hogy minél nagyobb mértékben kerül bevonásra a közfeladat-ellátásba a magánszektorbeli alany, annál nagyobb részét viseli a szerződéses megállapodással együtt járó kockázatoknak.

A Loxley által megalkotott bontás alapján a PPP-szerződések következő altípusait különböztetik meg a kisebb mértékü magánszektorbeli részvételtöl haladva a nagyobb felé (1. ábra):

- szolgáltatási, müködtetési és karbantartási szerződések (O\&M, Operation \& Maintenance),

- tervezési és építési szerződések (DB, Design-Build),

- tervezési, építési és működtetési szerződések (DBO, Design-Build-Operate),

- tervezési, finanszírozási, építési és lízingszerződések (DFBL, Design-FinanceBuild-Lease),

- tervezési, építési, finanszírozási, átruházási és müködtetési szerződések (BTO, Build-Transfer-Operate),

- tervezési, építési, működtetési és átruházási szerződések (BOT, Build-OperateTransfer),

- tervezési, építési, átruházási ${ }^{20}$ és működtetési szerződés (BOO, Build-OwnOperate).

19 SAVAS, Emanuel S.: Privatizáció - Hogyan vonuljon ki az állam a gazdaságból? Akadémiai Kiadó, Budapest, 1993, 19-27.

20 Az eredeti szövegben az „own” kifejezés szerepel, de lényegében a tulajdonos személyében beálló változásról van szó. 


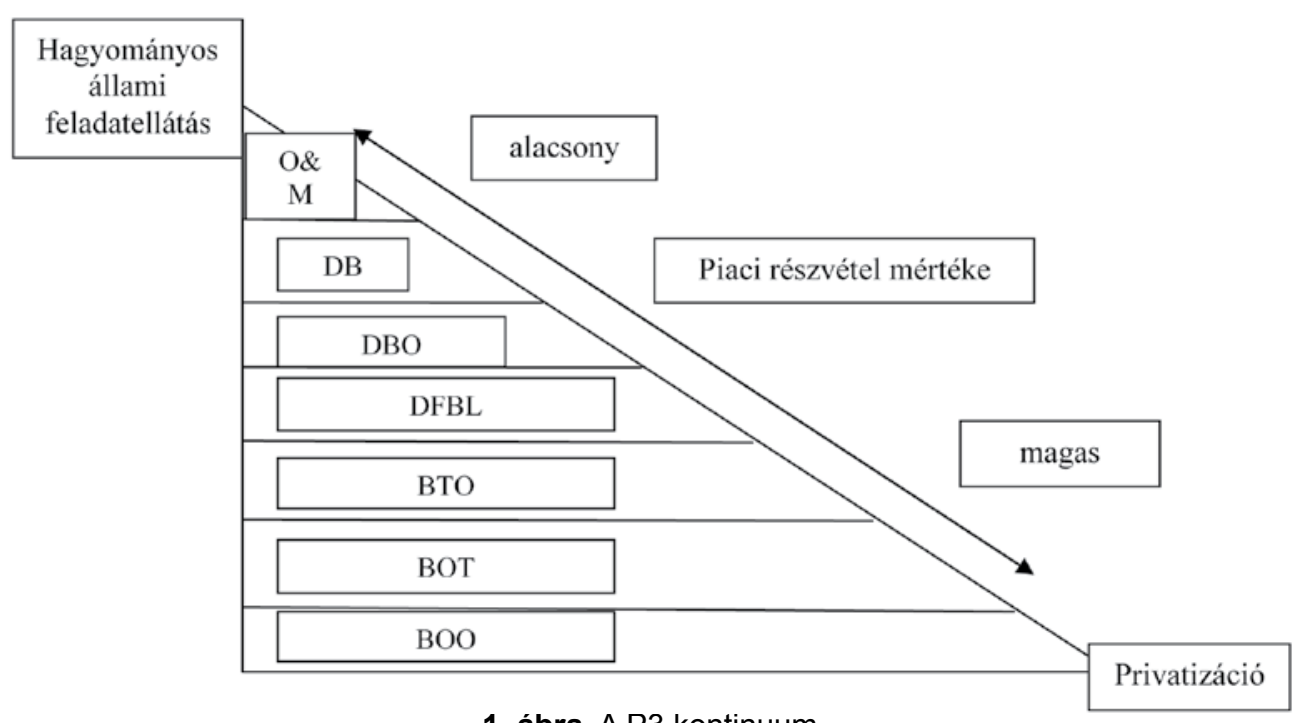

Forrás: LOXLEY

1. ábra. A P3 kontinuum

A Loxley által felvázolt tipizálás hibája, hogy csak a legáltalánosabban előforduló PPP-fajták kaptak helyet benne, így nem biztosít teljes áttekintést. Valamint az sem feltétlenül egyértelmü, hogy miért úgy súlyozta a szerződésfajtákat, ahogy tette. Nyilvánvaló persze, hogy az elsődleges szempont a magánszektorbeli partnerre háruló feladatok számossága volt, ez a legkisebb mértékủ piaci részvétellel járó kontraktusok esetén egyszerüen megállapítható. A probléma ott kezdődik, ha a piaci részvétel jelentősebb, és majdnem azonos feladatok hárulnak a magánszektorbeli félre. Ez utóbbi esetekben így nem egyértelmü, hogy milyen szempontok alapján ítélte meg a szerző azt, hogy mely ügyletek állnak messzebb a privatizációtól, s melyek állnak közelebb hozzá.

\subsection{A PPP mint a privatizáció eszköze}

Weber és Alfen a PPP-szerződésekre privatizációs megoldásként tekintenek. A szerzőpáros által alkalmazott csoportosítási lehetőség a Loxley-féle metódus továbbgondolásaként értelmezhető. A privatizációnak a szerzőpáros három típusát különbözteti meg: a formális, a funkcionális, valamint a tényleges privatizációt. ${ }^{21}$ Formális privatizáció alatt valamely államigazgatási szerv magánjog hatálya alá tartozó gazdasági társasággá alakítása értendő. A privatizáció célja ebben az esetben elsősorban a feladatellátás hatékonyságának előremozdítása, egyfajta menekülés a közszektor bürokratikus kötöttségei elöl. Ezt tekintik a leginkább elterjedt privatizációs megoldásnak. A funkcionális privatizáció alatt a szerzőpáros eredetileg az állam

21 Alfen-Weber: i. m., 55-62. 
által ellátott feladatok átadását érti magánszektorbeli alanyokra, mely megfeleltethető a kiszervezés (outsourcing) fogalmának. Ezen típusú privatizáció eszközei a különböző PPP-szerződések is. Az utolsó, a tényleges privatizáció, mely a Savas által szűkebb értelemben vett privatizációnak feleltethető meg. Itt arról van szó, hogy az állam teljes egészében kivonul valamilyen feladat ellátásából, szolgáltatás nyújtásából, s azok ellátását a magánszektorbeli profitorientált alanyokra bízza, mintegy magánjavakká22 minősítve az előbbieket.

A PPP-szerződéseket, mint a funkcionális privatizáció eszközeit, a szerzők két nagy csoportra bontják, melyek:

- szerződéses vagy vertikális PPP-k, valamint

- szervezeti vagy horizontális PPP-k.

A szerződéses vagy vertikális PPP-k lényege, hogy a közszektor által nyújtott szolgáltatások, feladatok elvégzéséhez szükséges, közkézben lévő infrastruktúrákkal kapcsolatban meghatározott feladatot vagy feladatokat (például tervezés, építés, működtetés, finanszírozás) transzferálják a magánszektorbeli partnerekre.

A szervezeti vagy horizontális PPP-k esetén nemcsak egyes feladatoknak a magánszektorbeli alanyokra történő átruházásáról van szó, hanem az infrastruktúra tulajdonjogának megosztásáról a felek között, vagy a tulajdonjog egészének magánszektorbeli alanyoknál való lecsapódásáról, ami jelenthet időleges (a szerződés futamidejéig tartó) vagy végleges (a szerződés lejártán túl terjedő) tulajdonjogot az infrastruktúra felett a magánszektorbeli alanyok számára.

A szervezeti vagy horizontális PPP-k közé sorolnak a szerzők néhány részlegesen megvalósuló, tényleges privatizációs megoldást is a funkcionális privatizációs eszközökön kívül. A szerzöpáros által meghatározott csoportosítási séma hiányossága, hogy sajnos nem különíti el egymástól a vertikális és a horizontális PPP-k közé tartozó szerződéstípusokat. Az egyes PPP-kontraktusokat csak aszerint bontja fel, hogy melyek tartoznak a funkcionális privatizáció, és melyek a részleges tényleges privatizáció eszközei közé (1. táblázat). Ez megítélésem szerint pótolható volna, ám létezik eme elméletnek egy problémásnak értékelhető eleme, konkrétan az, hogy nem tisztázza a részleges tényleges privatizáció fogalmát. Véleményem szerint ez alatt az egyes közfeladatok ellátásával összefüggő állami felelösség parciális átadására kerül sor magánszektorbeli alanyok számára. Ha így van, akkor miért kell elkülöníteni elöbbit a funkcionális privatizációtól? Sajnos erre a kérdésre nem kapunk kielégítő választ. 
1. táblázat. PPP-szerződések mint a privatizáció eszközei

\begin{tabular}{|c|c|}
\hline Funkcionális privatizációs eszközök & $\begin{array}{l}\text { Részleges tényleges privatizációs } \\
\text { eszközök }\end{array}$ \\
\hline $\begin{array}{l}\text { (D)B(F)OT - (tervezési)-építési- } \\
\text { (finanszírozási)-müködtetési-átruházási } \\
\text { szerződés }\end{array}$ & \multirow{2}{*}{$\begin{array}{l}\text { (D)B(F)OO - (tervezési)-építési- } \\
\text { (finanszírozási)-müködtetési-tulajdonlási } \\
\text { szerződés }\end{array}$} \\
\hline $\begin{array}{l}\text { (D)B(F)OOT - (tervezési)-építési- } \\
\text { (finanszírozási)-működtetési-tulajdonlási- } \\
\text { átruházási szerződés }\end{array}$ & \\
\hline $\begin{array}{l}\text { DBFO(T) - tervezési-építési-finanszírozási- } \\
\text { működtetési-(átruházási) szerződés }\end{array}$ & \multirow{2}{*}{$\begin{array}{l}\text { BDB(F)OO - vásárlási-tervezési-építési- } \\
\text { (finanszírozási)-működtetési-tulajdonlási } \\
\text { szerződés }\end{array}$} \\
\hline $\begin{array}{l}\text { (D)B(F)OOT - (tervezési)-építési- } \\
\text { (finanszírozási)-működtetési-tulajdonlási- } \\
\text { átruházási szerződés }\end{array}$ & \\
\hline $\begin{array}{l}\text { DBLOT - tervezési-építési-lízingelési- } \\
\text { müködtetési-átruházási szerződés }\end{array}$ & \multirow{2}{*}{$\begin{array}{l}\text { DB(F)ROO - tervezési-építési- } \\
\text { (finanszírozási)-bérleti-működtetési- } \\
\text { tulajdonlási szerződés }\end{array}$} \\
\hline $\begin{array}{l}\text { DB(F)ROT - tervezési-építési- } \\
\text { (finanszírozási)-bérleti-müködtetési- } \\
\text { átruházási szerződés }\end{array}$ & \\
\hline
\end{tabular}

Forrás: WeBER-AlfEN: i. m., 71-72, saját szerkesztés

\subsection{A PPP-megállapodások típusai tárgyuk szerint}

A Weber és Alfen által kidolgozott elmélethez nagyon hasonlít az Egyesült Királyságban alkalmazott csoportosítása e szerződéseknek, mely a brit kincstár fogalombázisára épít. Itt három nagy kategóriába sorolják a PPP szerződéseket attól függően, hogy mi képezi a szerződés tárgyát (2. ábra). Az első csoportba azok a megállapodások tartoznak, amelyek lényege, hogy az állami szervek, szervezetek átemelik a magánszektorbeli alanyok szervezeteinek müködése során alkalmazott technikákat, megoldásokat, annak érdekében, hogy a közintézmények müködését még hatékonyabbá, eredményesebbé tegyék. ${ }^{23}$

A másik kategóriába azok a szerződések tartoznak, melyek tárgya valamilyen infrastruktúra biztosítása és/vagy müködtetése. Ilyen lehet például a koncesszió vagy a franchise, amelyben a magánszektorbeli alany arra vállal kötelezettséget, hogy valamilyen közösségi szükségletet elégít ki egy szolgáltatás nyújtása révén, illetve opcionálisan az előbbi szolgáltatás ellátásához szükséges infrastruktúrát is biztosítja. Ezeket a megállapodásokat két kontinuum mentén lehetne csoportosítani: egyrészt az alapján, hogy melyik szerződéses partner nyújtja a szolgáltatást, illetve melyik biztosítja az előbbihez szükséges eszközöket. Ez alapján számos PPP-megállapodás létezhet kezdve attól, amikor a magánszektorbeli alany nyújtja a közszol-

23 A közmenedzsment, mint tudományos diszciplína, többek között az előbbi megvalósításának lehetőségeit járja körül. 
gáltatást a közszektor által létesített és tulajdonolt infrastruktúra segítségével, egészen azokig a típusokig, melyek esetén a közszektorbeli partner nyújt szolgáltatást a magánszektorbeli alany által létesített és tulajdonolt létesítményben.

A PPP-szerződések harmadik csoportját azok képezik, melyek a közszektor nyújtotta szolgáltatások kereskedelmi értékét növelik azáltal, hogy értékesítik azokat más piacokon is, ami leginkább a kormányzati kutatások eredményeinek szélesebb körben történö felhasználása esetén képzelhetö el. ${ }^{24}$

A szerzők az egyes PPP-típusokra konkrét szerződésfajtákból csak egy-két példát hoznak, ily módon akár utalhatnak arra is, hogy minden szerződés külön-külön vizsgálandó, s csak azt követően sorolható be az egyik vagy épp a másik nagy típusba.

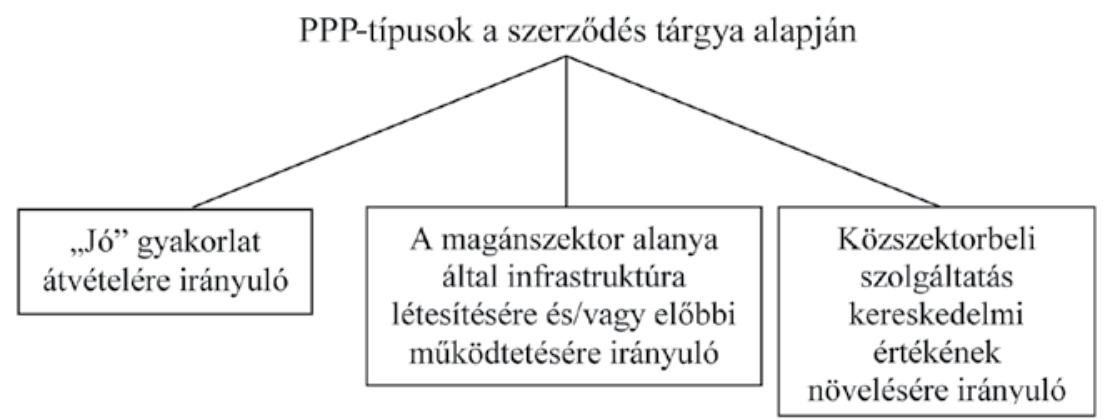

2. ábra. PPP-típusok a szerződés tárgya alapján

Forrás: saját szerkesztés

\subsection{A PPP-szerződések típusai a szolgáltató vezetése és a vagyonelemek feletti kontroll alapján}

A soron következő csoportosítási módszert a Világbank alkalmazza, s lényege az, hogy egy mátrixba rendezi a tipikusnak tekinthető PPP-megállapodásokat, mely mátrix egyik oldalán a szolgáltatást nyújtó vezetésére jogosult fél, $s$ ezzel a vezetés jellege, míg a másik oldalán a létrehozott vagy már meglévő vagyonelemek feletti kontroll gyakorlására jogosult fél szerepel (2. táblázat).

${ }^{24}$ McQuaID, Ronald W.-ScherRer, Walter: Public-Private Partnership in the European Union: Experience in the UK, Germany and Austria. Uprava, 2008, No. 2. 7-15. 
2. táblázat. PPP-szerződések csoportosítása

\begin{tabular}{|c|c|c|c|c|}
\hline & \multicolumn{3}{|c|}{ Vagyontárgyak feletti kontroll } \\
\hline & & $\begin{array}{l}\text { Közszektorbeli } \\
\text { alany }\end{array}$ & $\begin{array}{l}\text { Köz- és ma- } \\
\text { gánszektorbeli } \\
\text { alany együtt }\end{array}$ & $\begin{array}{l}\text { Magánszektor- } \\
\text { beli alany }\end{array}$ \\
\hline \multirow{3}{*}{$\begin{array}{l}\text { A } \\
\text { szolgál- } \\
\text { tató } \\
\text { vezetése }\end{array}$} & $\begin{array}{l}\text { Magánszektor- } \\
\text { beli alany }\end{array}$ & $\begin{array}{l}\text { menedzseri szer- } \\
\text { ződés, franchise, } \\
\text { O\&M }\end{array}$ & $\begin{array}{l}\text { lízingszerződés, } \\
\text { bérleti szerződés }\end{array}$ & $\begin{array}{l}\text { kiszervezés, } \\
\text { kiszerződés }\end{array}$ \\
\hline & $\begin{array}{l}\text { Köz- és ma- } \\
\text { gánszektorbeli } \\
\text { alany }\end{array}$ & $\begin{array}{l}\text { szolgáltatási } \\
\text { szerződések }\end{array}$ & vegyesvállalat & $\begin{array}{l}\text { BOT, BOOT, } \\
\text { BDFO, DCMF, } \\
\text { IPP, BOO }\end{array}$ \\
\hline & $\begin{array}{l}\text { Közszektorbeli } \\
\text { alany }\end{array}$ & $\begin{array}{l}\text { központi és helyi } \\
\text { kormányzat által } \\
\text { nyújtott szolgál- } \\
\text { tatás, létesített } \\
\text { infrastruktúra* }\end{array}$ & szövetségek & ** \\
\hline
\end{tabular}

* Ez hagyományos közfeladat-ellátási metódus, nem PPP.

** Nem értelmezhető a mátrixban.

Forrás: DeLmoN: i. m., 8.

A fenti táblázat több lényeges információval szolgál az egyes PPP-szerződések vonatkozásában, azonban a szolgáltató vezetésén és a vagyontárgyak feletti kontroll gyakorlóin túl a magánszektorbeli fél közfeladat-ellátásba vonásának mértékét is tartalmazza, s a feltüntetett szerződések között ily módon is különbséget tehetünk. A magánszektor közremüködésének mértékét az eredeti táblázatra felvezetett szürke nyíl jelzi. A nyíl talpánál azok a megállapodások foglalnak helyet, melyekben csekély (illetve nincs is) szerepe a magánszektorbeli alanynak, a nyíl hegye felé haladva a közszektorbeli alany közreműködésének mértéke egyre csekélyebb, míg végül megszünik.

E csoportosítási megoldás a korábban tárgyaltakhoz képest messze a leginformatívabb, ugyanakkor ez sem képes valamennyi lehetséges szempont egyidejü figyelembevételével csoportokba rendezni a tárgyalt megállapodásokat, illetve csak a leginkább elterjedt PPP-szerződések feltüntetésére vállalkozik.

\subsection{A PPP-megállapodások egyéb szempontok szerinti csoportosítása}

\subsubsection{Zöld- vagy barnamezős beruházás}

Szerződésről szerződésre vizsgálható, hogy zöld- vagy épp barnamezős beruházásokról van-e szó. Zöldmezősek azok, amelyek keretében újonnan valósítanak meg valamilyen beruházást, így például kollégium, börtön vagy autópálya megépítésére kerül sor. Míg barnamezősnek azok a konstrukciók nevezhetők, melyek már megvalósított létesítményekhez kapcsolódnak, mint építmény, létesítmény felújítá- 
sa, illetve egy meglévő létesítmény használata révén valamilyen szolgáltatás nyújtása. ${ }^{25}$

\subsubsection{Az újonnan létrehozott vagyon tulajdonjogának átszállása}

Ez a csoportosítási lehetőség a zöldmezős beruházások esetén merül fel, vagyis akkor, ha a szerződés teljesítése során új létesítményt hoznak létre. Ez alapján több lehetséges megoldás létezik, az egyik, hogy a létesítmény tulajdonjoga a szerződéses futamidő alatt az azt létrehozó fél tulajdonába száll, majd a futamidő végén vagy ingyenesen, vagy maradványértéken az a megrendelő (állam) tulajdonába kerül. A másik lehetőség, hogy a létesítmény tulajdonjogát nem szerzi meg a megrendelő a szerződési határidő lejártát követően sem. További alternatíva, hogy a létrehozó fél nem szerez tulajdonjogot az infrastruktúra felett sem a szerződés teljesítésének ideje alatt, sem annak lejártát követően.

\subsubsection{Finanszírozás alapján történő csoportba rendezés}

Mivel a PPP-szerződések keretében magas költségigényű beruházások valósulnak meg, így a magánszektorbeli alanyok gyakran kénytelenek saját tőkéjükön kívüli forrásokat is igénybe venni, hogy teljesíteni tudják szerződésben vállalt kötelezettségeiket. Ennek megfelelően akár aszerint is csoportba rendezhetnénk eme ügyleteket, hogy a közszektorral szerződő felek milyen forrásokból gazdálkodnak. A gyakorlat persze azt mutatja, hogy a legtöbb esetben több helyről származik a szerződések teljesítésének fedezete.

Egyrészt a magánszektorbeli alanyok költhetik saját tőkéjüket. Ebben az esetben értelemszerüen a legtöbb kockázatot is a magánszektorbeli alanyok viselik a szerződés teljesítése kapcsán.

A szükséges pénz származhat azonban hitelböl, illetve kölcsönböl, melyet nyújthatnak kereskedelmi bankok vagy más pénzpiaci szereplők, nemzetközi szervezetek vagy akár államok (tipikusan a megvalósítás helye szerinti állam).

\subsubsection{A szolgáltatás fogyasztói szerinti felosztás}

Az egyes megállapodások aszerint is osztályozhatók, hogy a magánszektorbeli alany által szerződésben felvállalt szolgáltatásokat - amennyiben az ügylet szolgáltatásnyújtásra (is) irányul - kik számára biztosítják: a közvetlen fogyasztóknak vagy magának az államnak, illetve más közvetítőnek, mely utóbbi esetben a szolgáltatást az állam vagy a közvetítő juttatja el a közvetlen igénybevevőkhöz. Ez esetben nem direkt módon nyújt a magánszektorbeli alany szolgáltatást az igénybe vevőknek, s így mentesül a közvetlen fogyasztókkal szembeni felelősség alól. ${ }^{26}$

25 Delmon, Jeffrey: Public-Private Partnership Project in Infrastructure. An Essential Guide for Policy Makers, Cambridge University Press, New York, 2011, 23-24.

26 Delmon: i. m., 39-44. 


\subsubsection{A PPP-szerződések bontása a magánszektorbeli partner bevételeinek forrása alapján}

A soron következö kategorizálási lehetőség szintén elsősorban a szolgáltatásnyújtásra (is) irányuló megállapodások esetén alkalmazható. A felosztás alapját a közszektorral szerződést kötő fél bevételének forrása adja.

E szerint három csoportba rendezhetjük az ügyleteket. Léteznek azok, amelyek esetén az állam fizet a vele szerződő félnek szolgáltatásaiért cserébe, vagyis az ellentételezésre közpénzböl kerül sor (központi vagy helyi költségvetésböl). A másik lehetőség, hogy a magánszektorbeli partner a fogyasztók által fizetett díjakból jut bevételhez. Nem ritka továbbá, hogy az első két megoldás valamilyen arányú keverékét választják a szerződő felek, vagyis hogy a szolgáltató dijjat szedhet a nyújtott szolgáltatásokért cserébe, ugyanakkor az állam is hozzájárul a szolgáltató költségeinek fedezéséhez kisebb vagy nagyobb mértékben.

Amennyiben egy szolgáltató kizárólag díjbevételekböl kénytelen fenntartani magát, nyilvánvaló, hogy a keresleti kockázatot ő viseli. Amennyiben az állam közpénzekböl elégíti ki a vele szerződő magánszektorbeli alany valamennyi költségigényét, illetve ő garantál számára elöre kikötött összegű profitot is, akkor a beruházással kapcsolatos valamennyi kockázat az államot terheli, s ily módon az Eurostat 2004-es határozata ${ }^{27}$ értelmében már nem is költségvetésen kívül elszámolható PPP-megállapodásról van szó. Amennyiben a magánszektorbeli alany közpénzböl és díjakból is bevételhez jut, akkor a szerződéssel kapcsolatos kockázatok megoszlanak a felek között. Annál nagyobb részben viseli a magánszektorbeli alany a szerződéses kockázatot, minél nagyobb arányban származik bevétele közvetlenül a fogyasztók által fizetett dijakból, s persze annál nagyobb a közszektorbeli alany kockázata, minél nagyobb arányban viseli ő a vele szerződéses kapcsolatban álló másik fél költségeit.

\subsubsection{Csoportosítás új - létesítményalapú - aspektusból}

Az eddigi, vagyis csak az infrastrukturális beruházásokra és az azokhoz kapcsolódó szolgáltatásokra fókuszáló csoportosítási nézőpont a gyakorlat által meghaladottá vált, hisz megjelentek olyan jószágok elóállitását célzó PPP-szerződések, melyek nem igénylik külön létesítmény felállítását (például tudásfejlesztés, versenyképesség-növelés). ${ }^{28}$

A PPP-szerződések mindig valamilyen közösségi igény kielégítésére születnek. Eme igények kielégítése a legtöbb esetben infrastrukturális létesítményhez kötődik, mely infrastruktúra tulajdonosa vagy maga az állam, vagy a magánszektorbeli partner. Ha magánszektorbeli szereplő a létesítmény tulajdonosa, van arra lehetőség, hogy idővel az állam megszerezze a tulajdonosi jogokat, de persze az az út is járható, ha erre az elöbbi jogátszállásra nem kerül sor. Akár az állam, akár a vele szerzödő másik fél a létesítmény tulajdonosa, lehet zöld-, illetve barnamezős beruházásról beszélni (3. táblázat).

27 Eurostat (2004): New decision of Eurostat on deficit and debt. Treatment of public-private partnerships. STAT/04/18. Forrás: http://europa.eu/rapid/press-release_STAT-04-18_en.htm (2015. 05. 22.).

28 Lásd Horizont 2020. 
3. táblázat. A PPP-szerződések csoportosítása az általuk célzott közösségi igény létesítményigénye alapján

\begin{tabular}{|c|c|c|c|c|c|c|c|c|c|c|}
\hline \multicolumn{6}{|c|}{ Önálló létesítményhez kötött közösségi igény } & \multirow{2}{*}{\multicolumn{5}{|c|}{$\begin{array}{l}\text { Önálló létesítményhez nem kötött } \\
\text { közösségi igény }\end{array}$}} \\
\hline \multicolumn{2}{|c|}{$\begin{array}{l}\text { Önálló létesít- } \\
\text { mény tulajdonosa } \\
\text { az állam }\end{array}$} & \multicolumn{4}{|c|}{$\begin{array}{l}\text { Önáló létesítmény tulajdonosa } \\
\text { a magánfél }\end{array}$} & & & & & \\
\hline \multirow[t]{4}{*}{$\begin{array}{l}\text { Zöld- } \\
\text { mezős } \\
\text { beru- } \\
\text { házás }\end{array}$} & \multirow[t]{2}{*}{$\begin{array}{l}\text { Barna- } \\
\text { mezős } \\
\text { beru- } \\
\text { házás }\end{array}$} & \multicolumn{2}{|c|}{$\begin{array}{l}\text { Az állam idővel } \\
\text { megszerzi } \\
\text { a létesítmény } \\
\text { tulajdonjogát }\end{array}$} & \multicolumn{2}{|c|}{$\begin{array}{c}\text { A létesítmény } \\
\text { tulajdonjoga } \\
\text { magánszektor- } \\
\text { beli félnél marad }\end{array}$} & \multirow[t]{2}{*}{$\begin{array}{l}\text { Nincs } \\
\text { szükség } \\
\text { kiszolgáló- } \\
\text { létesít- } \\
\text { ményre }\end{array}$} & \multicolumn{4}{|c|}{$\begin{array}{l}\text { Szükség van } \\
\text { kiszolgálólétesítményre }\end{array}$} \\
\hline & & $\begin{array}{l}\text { Zöld- } \\
\text { mezős } \\
\text { beru- } \\
\text { házás }\end{array}$ & $\begin{array}{l}\text { Barna- } \\
\text { mezős } \\
\text { beru- } \\
\text { házás }\end{array}$ & $\begin{array}{l}\text { Zöld- } \\
\text { mezős } \\
\text { beru- } \\
\text { házás }\end{array}$ & $\begin{array}{l}\text { Barna- } \\
\text { mezős } \\
\text { beru- } \\
\text { házás }\end{array}$ & & \multicolumn{2}{|c|}{$\begin{array}{l}\text { A kiszolgáló- } \\
\text { létesítmény } \\
\text { tulajdonosa } \\
\text { az állam }\end{array}$} & \multicolumn{2}{|c|}{$\begin{array}{l}\text { A kiszolgáló- } \\
\text { létesítmény } \\
\text { tulajdonosa } \\
\text { a magán- } \\
\text { szektorbeli } \\
\text { alany }\end{array}$} \\
\hline & & & & & & & zöld- & $\begin{array}{l}\text { bar- } \\
\text { na- }\end{array}$ & zöld- & $\begin{array}{l}\text { bar- } \\
\text { na- }\end{array}$ \\
\hline & & & & & & & \multicolumn{2}{|c|}{$\begin{array}{c}\text { mezős } \\
\text { beruházás }\end{array}$} & \multicolumn{2}{|c|}{$\begin{array}{l}\text { mezős } \\
\text { beruházás }\end{array}$} \\
\hline
\end{tabular}

Forrás: saját szerkesztés

A közösségi igények azonban, mint említettem, létesítményhez nem kötött „szolgáltatások" formájában is testet ölthetnek. Legtipikusabb példa erre a kutatások támogatása, tudásfejlesztés, innovációk támogatása. Nyilvánvaló, hogy egy közösség ismeretanyagának bővülése a versenyképesség növekedésével, s közvetve vagy közvetlenül az életkörülmények javulásával jár együtt, mely eredmények elérése a közösség igényei közé sorolandó. $E$ közösségi igények kielégítésére nem feltétlenül szükséges külön létesítményt felállítani. Ugyanakkor sok esetben a tudásanyag bővítéséhez bizonyos feltételekre szükség van, melyek biztosítása kiszolgálólétesítményeket (például laboratóriumok) igényel, melyek azonban a PPP-szerződés tárgyától függetlenül is működnek, funkcionálnak (például egyetemeken). Eme utóbbi esetben a PPP-szerződések célját segítő létesítményeket kiszolgálólétesítménynek is nevezhetjük, hisz azok saját feladattal és funkcióval, a PPP-szerződések létrejöttétől függetlenül müködnek.

\section{Leggyakrabban előforduló PPP-megállapodások}

A következőkben azokat a PPP-szerződéseket veszem sorra, melyek tipikusnak tekinthetők, vagyis leggyakrabban bukkannak fel. Ilyenek a BOO, a BOT, a BTO, a DBFO, illetve a koncessziós szerződések.

A BOO az angol build-own-operate kifejezésből származó mozaikszó, mely a magánszektorbeli partner fő kötelezettségeire utal. A BOO-ügyletekben a közszek- 
torbeli alannyal szerződő fél feladata a célzott infrastrukturális beruházás kivitelezése, müködtetése, s a létesítmény tulajdonjoga is őt illeti. A BOO-ügyletek között azonban különbség mutatkozhat a tekintetben, hogy ki az, aki a szolgáltatás ellenértékét megfizeti. A fizetési kötelezettség vagy a szolgáltatás közvetlen igénybe vevőit, vagy a közszektorbeli alanyt, vagy előző kettőt együtt valamilyen előzetesen rögzített arányban terheli. A PPP eme típusa áll legközelebb a privatizációhoz, mivel ebben az esetben valamennyi közszolgáltatással összefüggő feladat a közszektorral szerződő felet terheli, ahogy az ahhoz szükséges létesítmények tulajdonosa is ő.

Igen gyakori típusa a PPP-szerződéseknek az úgynevezett BOT (build-operatetransfer) megállapodás. Ebben az esetben az állammal szerződő fél vállalja a létesítmény megvalósítását és müködtetését, ám az infrastrukturális beruházás tulajdonjoga e felet csak a szerződési futamidő végéig illeti meg, utána az az államé lesz. Az állam vagy automatikusan tulajdont szerez a szerződési határidő végén a létesítmény felett, vagy maradványértéken vásárolja azt meg. A szolgáltatásért cserébe járó ellenértéket a BOO-szerződésekhez hasonlóan itt is vagy a közszektorbeli alany, vagy a szolgáltatás közvetlen használói, illetve valamilyen arányban e kettő együtt fizetheti meg.

A BTO (build-transfer-operate) ügyletek abban térnek el a BOT-szerződésektöl, hogy ezeknél a létesítmény tulajdonjogát a közszektorbeli alany annak kivitelezése után szerzi meg, így az már az elkészültét követően állami tulajdonba kerül. Bár ezt követően a vagyontárgy nem képezi a magánszektorbeli alany tulajdonjogát, továbbra is ő köteles a kapcsolódó szolgáltatás nyújtására a szerződésben kikötött határidő végéig.

Szintén nagyon gyakori PPP-megállapodásoknak számítanak a DBFO (designbuild-finance-operate) ügyletek. Ezeknél a kontraktusoknál az állammal szerződő fél tervezési, kivitelezési, az ezekkel összefüggő finanszírozási, valamint a müködtetési kötelezettségeket vállalja, ám az általa létrehozott létesítmények az állam tulajdonát képezik már megépítésük pillanatában. $A$ szolgáltatás nyújtója a magánpartner marad a szerződésben meghatározott időpontig vagy időtartamon keresztül. A szolgáltatás ellenértékét a szolgáltatónak az előző ügyletekhez hasonlóan vagy csak a közszektorbeli alany, vagy kizárólag a közvetlen igénybe vevők, vagy előbbi kettő együtt fizeti valamilyen arányban.

Az elöbbi ügyletek jelölésére ezek a betüszavak tekinthetök tipikusnak, ugyanakkor a BOT-szerződések feltűnnek bizonyos forrásokban BOOT-ként (build-ownoperate-transfer) is. A BTO helyett eme ügyletek BTL (build-transfer-lease), BLOT (build-lease-operate-transfer), illetve BLT (build-lease-transfer) rövidítése is használatban van, ahogy a DBFO jelölés helyett a DCMF (design-construct-managefinance) vagy a DBFM (design-build-finance-maintain) tünik fel a nemzetközi szakirodalomban. Előfordul, hogy ugyanazt a szerződéstípust más-más rövidítéssel jelölik, ennek oka nem a szerződések eltérő jellege vagy tartalma, hanem az egyes államok, illetve a nemzetközi szervezetek által használt jelölés különbözősége, illetve az, hogy ugyanazt a kötelezettséget eltérő módon jelölik az egyes államok, illetve nemzetközi szervezetek.

A koncessziós szerződés is tekinthető PPP-megállapodásnak, amennyiben az állam és egy másik közfeladat-ellátási szektorba tartozó alany között egy hosszabb 
időre szóló megállapodás születik, melynek tárgya valamilyen közfeladat, illetve közösségi igény kielégítésével függ össze. A koncesszió hazánkban az állam vagy a helyi önkormányzat által végezhető gazdasági tevékenységek gyakorlása jogának visszterhes szerződés keretében történő, időleges átengedését jelenti, ${ }^{29}$ melynek keretében az állam a koncessziós jog jogosultjának monopolhelyzetet ${ }^{30}$ garantál. $\mathrm{Az}$ ügylet tárgya itt is lehet valamilyen vagyontárgy létrehozása, annak müködtetése, illetve akár egy meghatározott tevékenység végzése is. A PPP eme típusa különösen nagy múlttal rendelkezik hazánkban és Közép-Európa más államaiban, népszerüsége napjainkban is töretlen.

\section{Zárógondolatok}

Az eddig folytatott vizsgálatokból megállapítható, hogy bár a nemzetközi szakirodalomban nincs teljes összhang a PPP fogalma tekintetében, de annak közös jegyeiben valamennyi szerző egyetért. Ezek ismeretében megállapítható, hogy a PPP kifejezés gyűjtőfogalom, amely magába olvaszt valamennyi, köz- és magánszektorbeli alany között közfeladat-ellátási céllal - legyen ez közösségi igényeket kielégítő infrastruktúrával összefüggő vagy attól független feladat - több évre létrejövő szerződéses megállapodást. A kapott definíció igen tágan határozza meg a PPP lényegét. A PPP-szerződések típusainak és csoportosítási lehetőségeinek tanulmányozását követően - felismerve, hogy a tárgyalt megállapodások sokszínüsége, s így a kategóriaképzés lehetőségeinek számossága okán; valamint abból a tényből kifolyóan, hogy a PPP mint jogintézmény számos egyéb jogtudományi és társadalomtudományi kérdéshez is kapcsolódik, s emiatt számtalan nézőpontból vizsgálható - levonható a következtetés, hogy olyan csoportképzési megoldás, mely egyidejüleg képes rendszerbe foglalni valamennyi ilyen szerződést, valamennyi szempont alapján, nem állítható fel. Ellenben valamennyi, a PPP gyüjtőfogalma alá tartozó közösségi igény kielégítésére létrejövő, a köz- és magánszektorbeli alanyok együttmüködésén alapuló megállapodás külön-külön, szerződésröl szerződésre vizsgálható, $s$ jellemezhető a korábban bemutatott tipizálási szempontok szerint.

\section{Abstract}

In this study the author examines the legal institution of PPP (Public Private Partnership) in Western legal cultures. As a result of the analysis, the author finds that PPP is a blanket term which includes all contracts concluded between public and non-public sectors where the subject of the contract is the implementation of a public task and the term of the contract is relatively long. The second part of the study collects and analyses the possible classifications of PPP contracts, including the short introduction of the most typical PPP contracts.

29 1991. évi XVI. törvény a koncesszióról 1. § és 13. §.

30 PAPP Tekla: Atipikus szerződések. Palatia, Szeged, 2007, 91-94. 